\title{
Labor Participation and Gender Inequalities in India: Traditional Gender Norms in India and the Decline in the Labor Force Participation Rate (LFPR)
}

\section{Alessandra Costagliola ${ }^{1}[0$}

Accepted: 30 June 2021 / Published online: 20 July 2021

(c) The Author(s) 2021

\begin{abstract}
Reduction in gender inequality has become a major component of development agendas, cited as a mechanism for improved access to health care, declining fertility rates, reduced poverty, and increased political and social participation of women. While women's participation in the labor force is an essential component of increasing gender equity in the developing world, such participation can only be made possible under conditions that allow women to possess the level of autonomy and mobility necessary for engaging in the labor market. In this article, I explain that while women's labor force participation is an essential component of gender equity, it is not the key to ensuring gender equality. To explain this, I examine India's decline in women's labor force participation rate (LFPR) despite its growing economy. I challenge arguments that rationalize that this decline is attributed to the U-shaped hypothesis, and I assert that this decline is associated with existing gendered notions of labor and persisting patriarchal and traditional values that discourage women from re-entering the labor force in the industrial and service sectors.
\end{abstract}

Keywords Labor force participation rate $\cdot$ LFPR $\cdot$ Gender equality $\cdot$ Women · India

\section{Introduction}

A major component of the Sustainable Development Goals (SDGs) set forth by the United Nations (UN), gender equality is an essential element to facilitating economic development. Women's participation in the labor market is one mechanism for achieving this, and it can create significant improvements in primary development objectives including reduced poverty; access to health care, education, land, technology, and

Alessandra Costagliola

Costagliola.alex@gmail.com

1 University of Westminster, London, UK 
capital; environmental sustainability; institutional effectiveness; and democratic participation (White 2006).

The literature demonstrates how the increase in women's labor force participation rate, henceforth LFPR, can lead to aspects of successful development and gender equity including increased availability of jobs, access to education, and a greater degree of decision making in the home (Chi-Wei et al. 2019). Considerable evidence demonstrates that empowering women can correlate with a reduction in fertility rate, reduced maternal mortality, as well as an increase in the average age at first marriage (Dreze and Sen 2013; Arora 2012). Indeed, as noted by Verick (2014), "female labor supply is...both a driver and an outcome of development."

LFPR is defined as "a measure of the proportion of a country's working-age population that engages actively in the labor market, either by working or by looking for work" (Verick 2014). The relationship between LFPR and economic growth has been suggested through a U-shaped relationship, meaning that as sectoral shifts occur during economic growth, female LFPR experiences a U-shaped trend as women exit and reenter the workforce, denoting that the two components are mutually conditioned (Lechman 2014). The U-shaped hypothesis describes this correlation, positing that "female participation rates are highest in poor countries, where women are engaged in subsistence activities and fall in middle-income countries because of the transition of (mainly) men to industrial jobs" (Verick 2014). As economic demand then shifts from the agricultural sector to the service sector, women are expected to re-engage in the labor market (Verick 2014).

As will be explored in this essay, women's LFPR, while an important component of economic development, is not the key to ensuring gender equality. I suggest that what Kabeer identifies as women's integration in development lying at the "bottom of an inherently hierarchical and contradictory structure" (Kabeer 1994) has been particularly detrimental to women's quest for gender equality in India. India presents an anomaly in terms of the U-shaped hypothesis, demonstrating an increased decline in women's LFPR as the economy continues to grow. Gender inequalities in India continue to persist despite women's participation in the labor market. Recent decline of women's participation in the labor market supports this notion. I argue that such an occurrence is a result of traditional and patriarchal views of women's role in society.

The objective of this paper is to demonstrate the factors that contribute to India's outlier position on the U-shaped curve. While the current literature denotes possibilities of India's outlier positioning primarily related to the income effect, education effect, and lack of job opportunities, as will be explored in this writing, I will aim to challenge these arguments, and instead propose that women's failure of re-entry into India's labor force is a direct result of patriarchal and traditional norms that prevent women from garnering gender equality. I argue that addressing gender inequity in India would lead to an increase in female labor force participation (ibid). 


\section{The U-Shaped Curve Explained}

Long-term trends demonstrate a decline in female LFPR at the country level over the last one to two decades. As noted by Sumanjeet (2016), 2014 indexes indicate that "a majority of countries worldwide show a positive trend in female workforce participation; the exceptions include India." Between 2005 and 2012, nearly 25 million women withdrew from the Indian wage labor market (Naidu 2015). While many researchers note that the decline is no cause for alarm, citing the U-shaped curve as a reflection of such decline, evidence suggests that components of the U-shaped curve effects, including increased education and income, are contradictory to the reality of women's experience in India.

India, however, is not the only contradiction to the U-shaped hypothesis. Turkey has experienced a similar decline in women's LFPR dropping from $36.1 \%$ in 1989 to $23.3 \%$ in 2005 (Verick 2014). Verick notes that this downward trend is a result of rapid urbanization and structural changes, which changed the scope of work for men and women as families transitioned from rural to urban areas (ibid). Other authors have explored the U-shaped phenomenon in other areas of the world as well. Altuzarra et al. (2019) explored the existence of a U-shaped relationship in two groups of EU member states, the EU-15, consisting of "old" EU member states (Luxembourg, Italy, Belgium, Greece, Spain, Ireland, France, Austria, Germany, Netherlands, UK, Portugal, Finland, Denmark, Sweden), and the EU-13, consisting of "new" EU member states (Malta, Bulgaria, Croatia, Poland, Romania, Czech Republic, Cyprus, Slovenia, Latvia, Slovakia, Lithuania, Estonia, Hungary). The authors concluded that while a U-shaped relationship was not present in the EU-15 due to their high-income economies during the period of analysis, a U-shaped curve was confirmed for the "newer" EU-13 member states (Altuzarra et al. 2019). Fatima and Sultana conducted a similar study of Pakistan and confirmed a U-shaped relationship largely attributed to "female education attainment, sectoral employment share, unemployment rate, wages, and marital status" (Fatima and Sultana 2009). Goldin also analyzed this relationship in regard to US economic development, concluding that the U-shaped relationship that existed in the USA could largely be contributed to female education: "With greater education for women and a larger white-collar sector, the income effect falls because more families no longer face the stigma effect of manufacturing work" (Goldin 1995).

While the above authors have indicated the existence of the U-shaped curve in specific regional contexts, authors including Verick and Gaddis and Klasen have argued otherwise. As noted by Verick, "Ultimately, women's employment is driven by a range of multifaceted factors, including education, fertility rates, social norms, and the nature of job creation" (Verick 2014). Gaddis and Klasen touch on this point further, noting that while a U-shaped relationship may have been observed in the development of some of today's advanced economies, such analysis is no longer relevant for developing countries today (Gaddis and Klasen 2014). Rather, they argue that "historically contingent initial conditions [are] more important drivers of female labor force participation than secular 
development trends" (Gaddis and Klasen 2014). As will be analyzed throughout the remainder of this writing, India's development, unlike the regions analyzed above, does not demonstrate a U-shaped relationship. Instead, female LFPR has declined and remains in decline even as India's GDP rises. Similar to Gaddis and Klasen and Verick, I argue that this failure to demonstrate a U-shaped relationship corresponds with initial conditions, that being social norms, which prevent women from actively engaging in the labor force.

\section{A Timeline of Women's Role in India's Development}

India's development began after its 1947 independence from British colonial rule. Initially, the economy grew at a slow rate of 3.5\% per year over the first three decades, but by the $1980 \mathrm{~s}$, economic growth quickened to $5 \%$ per year (Dreze and Sen 2013). The growth in the 1980 s was met with growing fiscal debts, however, and India avoided defaulting on its sovereign debt by pawning off gold to the bank of England (ibid). A structural adjustment program followed between 1991 and 1993, and a follow-up loan was declined (ibid).

By the 1990s, economic reforms had been implemented, allowing for a greater degree of openness to international trade, relaxation of internal controls, privatization of public enterprises, labor reforms, and foreign direct investment (FDI) in some sectors (ibid). While India's economic growth has made significant headway over the last several decades, it remains one of the poorest countries in the world. Unlike China, whose post-agricultural development segued into industrial manufacturing, India's growth has been largely attributed to "services" in skill-intensive sectors (ibid).

Trends in women's LFPR since India's economic boom have been particularly puzzling. Historically, women's primary role in the labor force has been in the agricultural sector. However, more and more Indian women working in this sector find themselves working primarily as unpaid labor in the field; all decision making related to non-field operations and marketing is left in the control of men (Banerjee 2002). Such a reality has reinforced sex segregation of women in the workforce, emphasizing the expectation that women should be tied to their household occupations. Research has posited several reasons for this outcome, including increased schooling, as well as the erosion of opportunities for women in this sector (ibid). For those women who do remain in the labor market, they often engage in unsustainable casual labor which restricts their ability to earn a higher income, exploits through long working hours and low-paid wages, and impedes their ability to exercise their voice (Arora 2012).

According to World Bank data, 2005 saw the highest rate of labor force participation among women at 31.79 percent (LFPR, World Bank, 2019). This coincides with the 127 percent increase in GDP between the years of 1995 and 2005, a 72 percent increase from the previous 10-year period (GDP, World Bank 2019). As GDP has continued to rise 241 percent since 2005, until the most recent data available in 2019, female LFPR has seen a sharp 34 percent decline in the same period (LFPR, World Bank, 2019; GDP, World Bank 2019). As GDP has risen in the 
country, service sector employment in India has grown faster than any other country in the world, accounting for nearly 50 percent of GDP (Statista 2021). As Kapsos et al. (2016) suggest, this increase in GDP, as well as declining fertility rates among women, should support increased female participation in the labor market, although the data demonstrate the opposite effect: With increasing GDP, India's female LFPR has continued to rapidly decline.

The reduction in LFPR for women in India has coincided with increased foreign direct investment (FDI) in India since 2005. The year 2008 saw the highest increase in FDI in the country's history, accounting for 3.62\% of GDP (Macro Trends 2021). The surge of investment over the last 15 years has increased GDP and household income, but the shift from an agricultural-based economy to a service-based economy with a high degree of occupational segregation has meant that women have limited opportunities available in the labor market. I suggest that with only $0.8 \%$ of men engaged in domestic duties in India as of 2012 data (Kapsos et al. 2016) domestic duties between couples are heavily unbalanced, making it more difficult for women to engage in the labor force, while still maintaining their domestic responsibilities. This, in conjunction with a segregated occupational landscape that fails to provide adequate support for domestic work like childcare, contributes to the continued decline of women's labor force participation.

Traditional roles of women have largely failed to evolve with the growth of the economy. Despite their integration into the labor market, women have continued to experience gender inequality. Economists have rationalized diminishing participation of women in developing labor markets as an associated effect of the "U-shaped" curve; however, such an approach has demonstrated India to be a significant outlier, with the existence of gendered norms and segregated occupational landscape playing a major role in the lack of women's economic development.

\section{India as an Outlier on the U-Shaped Curve}

The literature suggests that the U-shaped curve, described as the relationship between women's LFPR and economic development, explains why women's LFPR in India has been on the decline. The theory posits that women's entry into the labor force as agricultural laborers, followed by a decrease in LFPR due to a transition to industry as a result of higher income per household, is subsequently followed by a re-entry into the labor force, as fertility rates fall and education increases. Explanations for this decline have been argued as an income effect associated with educated women marrying into wealthier families (Chatterjee, 2018), increased attendance in education and higher household income levels (Chi-Wei et al. 2019), and low demand for women's labor force participation (Naidu 2015). The expectation of these explanations is that women's recess from the labor market induces them to engage in household duties, while their husbands maintain jobs in the industrial sector. Such is demonstrative of the effect of the division of labor and expectation of women to maintain domestic labor.

By examining the explained effects of the U-shaped curve in more detail, it becomes clear that women's lack of re-entry into the labor force can largely be 
explained by patriarchal and traditional norms set forth by Indian social and societal structures. In terms of the income effect, for instance, the argument that women retract from the labor market as household income increases appears incompatible with the notion that India remains one of the poorest countries in the world. As noted by Naidu (2015), "Women, according to this argument, can afford the luxury of not working for pay due to higher household income." Reality suggests that upon leaving the labor force, women become more focused on ensuring low levels of consumption for survival, evident from lower overall calorie consumption despite increased per-capita income (Naidu 2015). Basole and Basu explain this decline as a result of what they coin the "food budget squeeze hypothesis" which "advances the possibility that the cost of meeting the non-food essentials has increased so fast that it has squeezed the food budget, leaving insufficient purchasing power for food" (Basole and Bassu 2015). Women's inability to engage in the labor force results in such budget squeeze as the cost of expenditures rise.

Further, when examining the education effect, denoted by women's decline in LFPR as a result of pursuing higher levels of education, it is noted that education and literacy levels tend to be conflated (Swaminathan 2002). Evidence suggests in Tamil Nadu, for instance, that while literacy rates are relatively high, formal education tends to be quite poor (Swaminathan 2002). Even still, UNESCO data demonstrates that enrollment in secondary and even tertiary education for both male and females is on the rise, as well as rising completion rates of secondary schooling. In fact, in 2016 male secondary school enrollment (gross \%) was 74.5\%, while female enrollment rate tagged not so far behind at $62 \%$. Further, lower secondary completion rates (as a percent of relevant age group) are higher for females at $87.6 \%$ in 2017 compared to males at $82.7 \%$ in the same year (UNESCO Institute for Statistics). Such data begs the question-if females are pursuing and completing an education at the same rate as males, why does female LFPR remain so low? Further, even when women do obtain a level of education relative to their male counterparts, they struggle to obtain career positions that are of equal standing.

The lingering notion that women's decline in LFPR in India is a result of a lack of job opportunities open to women does two things. Firstly, it denies the notion that India's growth has been largely attributed to the service sector, not the industrial sector (Dreze and Sen 2013). As predicted by the U-shaped hypothesis, if jobs for women are anticipated to increase when an economy transitions to a service sector economy (Verick 2014), why has this not been the case for women in India? Secondly, this notion exacerbates the understanding of the gendered nature of the division of labor, assuming that women cannot engage in the industrial economy, despite the fact that China's manufacturing sector employs a significant number of women. The expectation remains that women's duties lie in the household and that work-related activities must accommodate these duties. Women's participation in the agricultural sector allowed for a balance of duties, but with the transition to industrial and service sector employment, women face challenges of maintaining this balance and are thus discouraged by their families to enter these sectors. This notion leads to the argument that a gendered understanding of labor will continue to persist so long as patriarchal and traditional conceptions of gender exist. As Neff et al. (2012) notes, "the main reason that women give for why they are not part of 
the labor force (according to their activity status) is that they are doing domestic work (85 percent), which is a sign of patriarchal gender roles and norms." Further, as noted by Klasen and Pieters, a resistance against women's employment in whitecollar jobs can take place when the number of educated men is in excess as this would "reduce the opportunities for men" (Klasen and Peiters 2013). Such prioritization of male employment over female employment, even when presented with the same level of education, clearly indicates the existence of a gendered workforce.

Indeed, data highlighted by Kapsos et al. (2016) suggest that $33.6 \%$ of rural female working-age population in India cite domestic duties for the reason they are not active in the formal labor market. Additionally, the authors estimate that $42 \%$ of the decline in female LFPR can be attributed to lack of employment opportunities for women, with occupations predominantly held by females experiencing little to no growth overall (ibid). The authors note of the ten fastest growing occupations in India, less than $19 \%$ of new employment opportunities in these occupations have been taken up by women, and the increase in female growth is only seen in three out of these ten occupations (ibid). This suggests that despite increasing investment in the economy, gendered employment segregation, fuelled by traditional gendered norms, disables women from having significant opportunities in the Indian labor market, particularly as the country has cultivated its service sector over the last fifteen years. Further, as noted above, the lack of opportunities for women, in conjunction with unbalanced workload of domestic duties in the home, contributes to women's lack of engagement in the labor market overall.

\section{Other Dimensions of Gender Inequality in India}

Although the economy continues to grow in India, traditional notions of women's position in society have failed to diminish and have only been reinforced through negative social attitudes, familial preferences for males, and increased violence against women. Traditional norms and customs relegate women to a "secondary status within the household and workplace" (Sumanjeet 2016). Large parts of Indian society discourage women from entering the workforce based on negative social attitudes toward women's work. As noted by Banerjee (2002), “women's training and socialization at the household level continue to be tailored to those same household-oriented roles."

Traditional understanding of a woman's role in Indian society has discouraged women from gaining autonomy, independence, and voice. Cultural expectations associated with "menarche" or "coming of age" require an emphasis on honor, limited mobility, and often a discontinuation of schooling. Further, young women are encouraged to marry at an early age to preserve their honor and ensure premarital virginity (Banerjee 2002). India has the highest number of child brides in the world, at about 24 million (Sumanjeet 2016). Marriages are contingent on the offer of a dowry from the bride's family to the husband, and often, this money is used for investments that do not directly benefit the bride (e.g., buying or cultivating land, purchasing a cycle or tractor, or setting up a shop) (Banerjee 2002). Because the practice of dowry has become so heavily intertwined with status and caste in Indian 
society, parents struggle to challenge the practice "for fear of its adverse impact on the lives of their daughters" (Swaminathan 2002).

For most child brides, early marriage means early child rearing, a practice that has not only potential detrimental health-related consequences to young women, but also reinforces the expectation of domestic duties from a very early age. Early child rearing can often limit mobility and denies women the freedom to engage in other pursuits (Dreze and Sen 2013). When young women begin having children, a cultural preference for boys further exacerbates the existence of gender inequality in the country. As a result, the country is currently faced with an unnatural shortage of girls due to the occurrence of female infanticide. For those female children that are born, systematic neglect leaves them with a higher mortality rate relative to boys. Although fertility rates are on the decline, contrary to the U-shaped hypothesis, this decline has not induced higher levels of female LFPR.

Additionally, women face severe challenges when it comes to violence perpetrated against them. Crimes against women are reported in India every $1.7 \mathrm{~min}$ (Sumanjeet 2016) and often take the form of honor killings, including dowry deaths, domestic violence, and rape. Rape has become an increasingly problematic occurrence in India over the years, with a rape recorded approximately every 16 minutes (Sumanjeet 2016). As noted by Dreze and Sen (2013), "India does indeed have a 'rape problem'." Often such violence goes unpunished or unreported and augments men's dominance, reinforcing patriarchal notions of men's position relative to women in society. In 2020, Human Rights Watch reported the Indian governments' failure to enforce its 2013 Sexual Harassment of Women at Workplace (Prevention, Prohibition and Redressal) Act (POSH), finding that female employees, particularly in the informal sector, are at risk of sexual abuse due to lack of enforcement (Human Rights Watch 2020). This has prevented many women from feeling safe enough to engage in the labor force.

\section{Addressing Social Perceptions: Reducing Gender Inequalities in India}

Although women's inclusion in the labor market, particularly in agriculture, has been crucial to the improved economic landscape of India, it is not the key factor in addressing gender inequality in India. Rather, addressing traditional and patriarchal institutions that allow gender-based violence and gender inequity to persist is the key to ensuring gender equality in India.

As noted above, the decline in women's LFPR in India cannot merely be explained by the existence of a U-shaped curve. India is proven to be an outlier in this hypothesis, and this anomaly can largely be attributed to the existing traditional and patriarchal notions of women's role in Indian society. Re-entry from agriculture into the service sector fails to occur for women in India due to challenges associated with maintaining balance between household duties and work-related activities once women are in the service sector, as well as general negative perceptions associated with women's participation in the labor market. 
Women's re-entry into the labor market in India is heavily dependent on closing the gender gap. In order to do this, societal perceptions of women's role in society must adapt to an evolving economic atmosphere. Closing the gender gap in India will further benefit the economy through "the impact of female education on fertility, child mortality, and the creation of human capital in the next generation" (Sumanjeet 2016). Global integration of both men and women cannot take place unless there is a reduction in gender inequality requiring a social transformation to take place through "change in deep-rooted attitudes beginning at the family level" (Arora 2002).

\section{Policy Recommendations to Encourage Female LFPR}

Dasgupta and Verick (2016) suggest four pillars of policies that can contribute to increased participation for Indian women in the labor market. These include inclusive growth and job creation; education and skills development; support for reducing time burden; transport and infrastructure; legal rights and protection; and measurement. As Dasgupta and Verick suggest, reducing the time burden associated with unpaid domestic activities will enable women to make choices about paid work and policies including flexible work, shared responsibilities at the household level, and maternity benefits can contribute to this activation of choice (ibid). In addition to reducing the burden associated with unpaid household work, policies that provide economic benefit or compensation for these household duties may not only equalize the distribution of labor in the household, but would also equalize women's financial contribution to the household and acknowledge that her unpaid work is indeed labor intensive. Many Western countries have pressed the need for a basic income for stay-at-home parents, and the same approach should be considered for India given that such a significant portion of its female labor force is not employed in the formal economy, but contributes to the economy in other ways, including via domestic work.

Additionally, establishing quotas that bolster the number of women in each industry would provide guaranteed access for women in the labor market. Companies could be incentivized by the government to fill these quotas and provide adequate training and support to the women they employ. Such an approach would not only provide women access to industries where they may currently face barriers, but also de-segregate gendered occupations.

Lastly, in addition to economic policies that enable women's participation in the labor force it is important to address the ways to combat other dimensions of experienced gender inequality that may also contribute to a lack of female LFPR. As noted above, both early marriage and violence against women are common practices that discourage women from entering the labor market. The Indian government and local authorities must work to enforce laws and policies that are intended to protect women in these circumstances and punish perpetrators who cause harm to women. So long as this enforcement is consistent and widespread, it will help to reshape the social norms associated with women's position in society and challenge the 
patriarchal structures that have enabled the astronomical rates of violence against women to occur.

\section{Conclusion}

Although women's participation in the labor market is an essential factor in cultivating gender equity in the context of development, as demonstrated in the above example in India, it is not the key to addressing gender inequality. Addressing traditional and patriarchal notions of women's role in society, as well as breaking down dated notions of gendered labor, is key to ensuring women's autonomy, mobility, and participation in the labor market, and more holistically speaking, in development strategies.

This essay has argued that while the literature demonstrates an existing U-shaped curve that attempts to explain women's decreased LFPR in India over the last decade plus, evidence demonstrates that the explained rationale behind this decline is not aligned with the reality of Indian women's experience. The income and education effects of the U-shaped curve fail to explain decreased levels of consumption, decreasing fertility rates, and existing norms and expectations of women's duties in the home. Further, current rates of secondary and tertiary school enrollment and completion being equivalent to that of males should induce female LFPR. Familial and societal expectations that limit women's autonomy and mobility outside of the home in conjunction with gendered occupational norms have denied women the ability to re-enter the labor force in the industrial or service sector despite their substantial participation in the agricultural sector, including the regularity of women working as free laborers on their husband or family's property.

Re-entry of women into the labor force can only occur if patriarchal and traditional notions of women's position in society are challenged and societal expectations are deconstructed. As suggested, policies that can enable this include flexible work for women, maternity leave, paid domestic work, female gender quotas across industries, and enforcement of laws that protect women from violence and early marriage. Once this has occurred, women can enjoy a degree of autonomy and mobility that benefits the growing economy and leads to improvements in other developmental areas including fertility rates, child mortality rates, and increased education.

While this analysis has primarily oriented itself utilizing data at the country level, there is certainly opportunity to expand upon this by providing analysis on a household or individual level. Such analysis could unveil the participation rates of females who are both educated and have higher income levels.

Funding The author recieved no funding for this research.

Conflict of interest The author has no conflict of interests.

Open Access This article is licensed under a Creative Commons Attribution 4.0 International License, which permits use, sharing, adaptation, distribution and reproduction in any medium or format, as long as you give appropriate credit to the original author(s) and the source, provide a link to the Creative 
Commons licence, and indicate if changes were made. The images or other third party material in this article are included in the article's Creative Commons licence, unless indicated otherwise in a credit line to the material. If material is not included in the article's Creative Commons licence and your intended use is not permitted by statutory regulation or exceeds the permitted use, you will need to obtain permission directly from the copyright holder. To view a copy of this licence, visit http://creativecommons.org/ licenses/by/4.0/.

\section{References}

Altuzarra, Amaia, Catalina Gálvez-Gálvez, and Ana González-Flores. 2019. Economic Development and Female Labour Force Participation: The Case of European Union Countries. Sustainability 11 (7): 1962. https://doi.org/10.3390/su11071962.

Arora, R. 2012. Gender Inequality, Economic Development, and Globalization: A State Level Analysis of India. The Journal of Developing Areas 46 (1): 147-164. https://doi.org/10.1353/jda.2012.0019.

Banerjee, N. 2002. 'Between the Devil and the Deep Sea Shrinking Options for Women in Contemporary India.' In Kapadia, K. (ed) The violence of development: the politics of identity, gender and social inequalities in India / edited by Karin Kapadia. London: Zed Books.

Basole, \& Basu. . 2015. Fuelling Calorie Intake Decline: Household-Level Evidence from Rural India. World Development 68 (1): 82-95. https://doi.org/10.1016/j.worlddev.2014.11.020.

Bhattacharya, P. 2006. Economic Development, Gender Inequality, and Demographic Outcomes: Evidence from India. Population and Development Review 32 (2): 263-292. https://doi.org/10.1111/j. 1728-4457.2006.00118.

Chatterjee, E., et al. 2018. Indian Paradox: Rising Education, Declining Women's Employment. Demographic Research 38 (1): 855-878. https://doi.org/10.4054/demres.2018.38.31.

Chi-Wei, S., L. Zheng-Zheng, and R. Tao. 2019. Can Economic Development Boost the Active Female Labor Force? Quality and Quantity 53 (2): 1021-1036. https://doi.org/10.1007/s11135-018-0800-z.

Cooke, F. 2010. Women's Participation in Employment in Asia: A Comparative Analysis of China, India, Japan and South Korea. The International Journal of Human Resource Management 21 (12): 22492270. https://doi.org/10.1080/09585192.2010.509627.

Dasgupta, Sukti, and Sher Singh Verick. 2016. Transformation of Women at Work in Asia. New Delhi: SAGE Publications.

Drèze, J., and A. Sen. 2013. An Uncertain Glory: India and its contradictions. London: A. Lane.

Fatima, A., and H. Sultana. 2009. Tracing Out the U-shape Relationship Between Female Labor Force Participation Rate and Economic Development for Pakistan. International Journal of Social Economics 36 (1/2): 182-198. https://doi.org/10.1108/03068290910921253.

Gaddis, I., and S. Klasen. 2014. Economic Development, Structural Change, and Women's Labor Force Participation. Journal of Population Economics 27 (3): 639-681. https://doi.org/10.1007/ s00148-013-0488-2.

Goldin, C. 1994. The U-Shaped Female Labor Force Function in Economic Development and Economic History [Online].

Human Rights Watch. 2021. India: Women at Risk of Sexual Abuse at Work. [online] Human Rights Watch. Available at: https://www.hrw.org/news/2020/10/14/india-women-risk-sexual-abuse-work\#

ILO, Key Indicators of the Labour Market, 8th Edition. Retrieved from https://datacatalog.worldbank.org/ International Labour Office. 2012. Global employment trends for women 2012. IDEAS Working Paper Series from RePEc, IDEAS Working Paper Series from RePEc, 2012. https://doi.org/10.5848/ilo. 978-9-221266-58-7_2.

Kabeer, N. 1994. Chapter 3: Same Realities, Different Windows: Structuralist Perspectives on Women and Development. In Reversed Realities: Gender Hierarchies in Development Thought, 40-68. London: Verso.

Kapadia, K. 2002. The Violence of Development: The Politics of Identity, Gender and Social Inequalities in India. London: Zed Books.

Kapsos, Silberman, and Bourmpula in Dasgupta, Sukti, \& Verick, Sher Singh. . 2016. Transformation of Women at Work in Asia. New Delhi: SAGE Publications. 
Klasen, S., and J. Pieters. 2015. What Explains the Stagnation of Female Labor Force Participation in Urban India? The World Bank Economic Review 29 (3): 449-478. https://doi.org/10.1596/ 1813-9450-7222.

Lahoti, R., and H. Swaminathan. 2015. Economic Development and Women's Labor Force Participation in India. Feminist Economics 22 (2): 1-28. https://doi.org/10.1080/13545701.2015.1066022.

Lechman, E. (2014). Female labor force participation and economic growth- re-examination of U-shaped curve. IDEAS Working Paper Series from RePEc, IDEAS Working Paper Series from RePEc, 2014. https://doi.org/10.2139/ssrn.2409864.

Macro Trends. (2021). India Foreign Direct Investment 1970-2021. [online] Macrotrends.net. Available at: <https://www.macrotrends.net/countries/IND/india/foreign-direct-investment>

Naidu, S. 2015. Missing Women Workers: Explaining the Decline in Women's Labor-Force Participation in India. Dollars \& Sense 320: 30.

Neff, et al. 2012. The Puzzling Decline in Rural Women's Labor Force Participation in India: A Reexamination. IDEAS Working Paper Series from RePEc, IDEAS Working Paper Series from RePEc, 2012. https://doi.org/10.2139/ssrn.2143122.

Statista. (2021). India - Distribution of gross domestic product (GDP) across economic sectors 2019 । Statista. [online] Statista. Available at: <https://www.statista.com/statistics/271329/distribution-ofgross-domestic-product-gdp-across-economic-sectors-in-india/ $>$

Sumanjeet, Singh. 2016. The State of Gender Inequality in India. Gender Studies 15 (1): 139-157. https:// doi.org/10.1515/genst-2017-0009.

Swaminathan, P. 2002. 'The Violence of Gender-Biased Development: Going Beyond Social and Demographic Indicators.' In Kapadia, K. (ed) The Violence of Development: The Politics of Identity, Gender and Social Inequalities in India. London: Zed Books.

Verick, S. 2014. Female Labor Force Participation in Developing Countries. IZA World Labor 87: 1-10. https://doi.org/10.15185/izawol.87.

White, S.C. 2006. The "gender lens": A Racial Blinder? Progress in Development Studies 6 (1): $55-67$. https://doi.org/10.1191/1464993406ps127oa.

World Bank, World Development Indicators. (2019). Fertility Rate, Total (Births per Woman). https:// data.worldbank.org/indicator/sp.dyn.tfrt.in

World Bank, World Development Indicators. (2019). GDP per capita (current US\$). https://data.world bank.org/indicator/ny.gdp.pcap.cd

World Bank, World Development Indicators. (2019). Labor force participation rate, female (\% of female population ages 15+) (modeled ILO estimate). https://data.worldbank.org/indicator/SL.TLF.CACT. FE.ZS

World Bank, World Development Indicators. (2019). Labor force participation rate, male (\% of male population ages 15+) (modeled ILO estimate) https://data.worldbank.org/indicator/SL.TLF.CACT. MA.ZS

UNESCO Institute for Statistics. World Bank, World Development Indicators. (2019). Lower secondary completion rate, female (\% of relevant age group. https://data.worldbank.org/indicator/SE.SEC. CMPT.LO.FE.ZS

UNESCO Institute for Statistics. World Bank, World Development Indicators. (2019). Lower secondary completion rate, male (\% of relevant age group. https://data.worldbank.org/indicator/SE.SEC. CMPT.LO.MA.ZS

UNESCO Institute for Statistics. World Bank, World Development Indicators. (2019). School Enrollment, Secondary, Female (\% gross). https://data.worldbank.org/indicator/SE.SEC.ENRR.FE

UNESCO Institute for Statistics. World Bank, World Development Indicators. (2019). School Enrollment, Secondary, Male (\% gross). https://data.worldbank.org/indicator/SE.SEC.ENRR.MA

UNESCO Institute for Statistics. World Bank, World Development Indicators. (2019). School Enrollment, Tertiary, Female (\% gross). https://data.worldbank.org/indicator/SE.TER.ENRR.FE

UNESCO Institute for Statistics. World Bank, World Development Indicators. (2019). School Enrollment, Tertiary, Male (\% gross). https://data.worldbank.org/indicator/SE.TER.ENRR.MA

Publisher's Note Springer Nature remains neutral with regard to jurisdictional claims in published maps and institutional affiliations. 